\title{
STABILITY OF RAPESEED (Brassica napus L. ) VARIETIES UNDER RAINFALL CONDITIONS IN NORTHEREN OF IRAQ
}

\author{
Mohammed Y. Hammed
}

Dept. of Felid Crops , College of Agric. and Forestry, Mosul Univ., Iraq

\begin{abstract}
Four rapeseed varieties, Paktol, Kebel, Forte and Karat were tested in five environments represented limited and semi-limited dryland area in northern of Iraq, Mosul province (Rashidia during 1999-2000 and 2000-2001, singar during 2000-2001 and Bashiqa site during 2000-2001 and 2001-2002 seasons) in order to determine stability of these varieties for plant height, heading,yield and its components.Significant varietal and environments differences were observed for the traits investigated except no. of seed per pod and 1000 seed weight.GXE interaction effect was highly significant for all traits except 1000 seed weight. Paktol were better adapted to favorite environments for plant height, no. of days to heading and no. of pods per plant and better adapted to a wide of environments and stable for seed yield.
\end{abstract}

\section{INTRODUCTION}

Oil rapeseed (Brassica napus L.)is now the second largest oilseed crop in the word providing $13 \%$ of the world supply. The world s' commerce is largely supplied by two species, Brassica napus and B. rapa L. Both species contain both spring and winter form that are distinguished by vernalization requirement (Raymer, 2002). Seeds of these species commonly contain $40 \%$ or more oil and produce meals with $35-40 \%$ protein. Limited water supply is a major problem for crop production in Mediterranean environments (Blum and Pnuel, 1990). The efficiency with which a crop uses water may reflect crop performance and it provides a means for comparing environments (Perry, 1987) . Different genotypes perform differently in different environments and their growth habit is one of the principle descriptors of this variation (Kretchmer et al., 1979).

To improve the stability of varieties, adaptive traits that affect yield response across environments must be identified as the basis of an effective breeding program. Donald (1968) suggested the importance of having a model (ideotype) as a goal for breeding programs. Fall - seeded rapeseed was studied in five field experiments at Milan in northwest Tennessee during 1986-87, yields ranged from $2150 \mathrm{~kg} /$ ha for 'Viking' to $3140 \mathrm{~kg} /$ ha for 'Gorezanski' (Fribourg et al.,1990). Research has demonstrated that the diversity of form, usage and adaptability among Brassica species has generated wide interest in crucifers as potential new crops (Williams, 1990) .

Christmas (1996) reported that cultivar performance varied by site indicating that some cultivars may be more tolerant to adverse weather than others.'Touchdown' appears to be the best performer under adverse conditions while 'Liborius' was the poorest performer. In order to project a mean yield for 
Virginia farmers, Starner et al. (2002) used five best performing entries from 1998-1999, 1999-2000 and 2000-2001 trials. The result indicated that seed yield means varied from $1951 \mathrm{~kg} / \mathrm{ha}$ for ARC91023-63L-5 to $3179 \mathrm{~kg} / \mathrm{ha}$ for UGA96200E with an overall average of $2364 \mathrm{~kg} / \mathrm{ha}$.

Received 22/2/2005

Accepted 11/5/2005

The aim of this study was to determine stability of introduced rapeseed varieties for yield and its components and its performance under limited and semi-limited rainfall conditions in northern of Iraq.

\section{MATERIALS AND METHODS}

Four rapeseed varieties, Paktol, Kebel, Forte and Karat were sowing in five environments represented limited and semi-limited dryland area in northern of Iraq , Mosul province (Rashidia during 1999-2000 and 2000-2001, singar during 2000-2001 and Bashiqa site during 2000-2001 and 2001-2002 winter growing seasons of a varied rainfall precipitation) using Randomized Complete Block Design with three replications.

The experimental plot comprised 5 rows, each $5 \mathrm{~m}$ long and spaced $40 \mathrm{~cm}$ apart. The sowing rate was $2 \mathrm{~kg} /$ donum.. The precipitated amount of rain and temperature during the three seasons for studied sites showed in table 1 .It is noticed that the amounts of rain during growth season 1999 is very low and under general average, therefore the crop received eight irrigations during growth season in Rashidia.

Table (1): Rainfall and temperature at Rashidia , Singar and Bashiqa over the period 1999-2002 .

\begin{tabular}{|c|c|c|c|c|c|c|c|c|}
\hline \multirow{3}{*}{ Month } & \multicolumn{8}{|c|}{ Locations } \\
\hline & 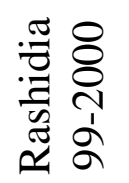 & 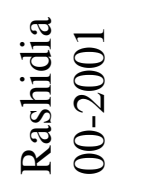 & 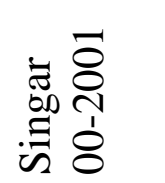 & 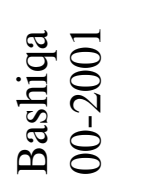 & 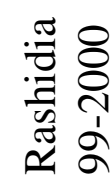 & & 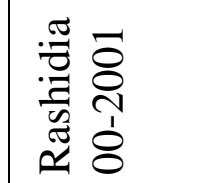 & 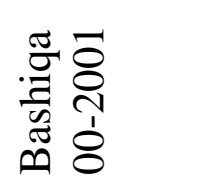 \\
\hline & \multicolumn{4}{|c|}{ Rainfall (mm) } & \multicolumn{4}{|c|}{ Temperature $\mathrm{C}^{\circ}$} \\
\hline Oct. & 10.5 & 12.4 & 13.5 & 15.0 & 14.7 & 31.8 & 13.028 .4 & 13.029 .4 \\
\hline Nov. & 8.2 & 46.7 & 47.2 & 55.0 & 6.6 & 21.8 & $6.9 \quad 21.4$ & $\begin{array}{ll}7.1 & 22.2\end{array}$ \\
\hline Dec. & 28.0 & 83.7 & 164.2 & 114.0 & 3.3 & 16.8 & $\begin{array}{ll}5.1 & 13.9\end{array}$ & 5.114 .0 \\
\hline Jan. & 52.6 & 25.9 & 35.8 & 35.0 & 2.4 & 12.0 & $3.0 \quad 14.1$ & $4.4 \quad 13.0$ \\
\hline Feb. & 23.7 & 37.9 & 48.0 & 37.0 & 2.3 & 15.1 & $4.1 \quad 15.8$ & $4.1 \quad 15.8$ \\
\hline Mar. & 31.1 & 82.5 & 121.8 & 107.0 & 4.0 & 19.3 & $\begin{array}{ll}9.5 & 22.2\end{array}$ & $\begin{array}{ll}9.5 & 22.3\end{array}$ \\
\hline Apr. & 22.3 & 36.2 & 12.5 & 32.0 & 3.7 & 28.5 & $10.8 \quad 26.2$ & $10.8 \quad 25.9$ \\
\hline May & 0.3 & 17.6 & 21.0 & 15.0 & 17.3 & 34.1 & $\begin{array}{lll}15.0 & 32.3\end{array}$ & 15.132 .6 \\
\hline June & 0.0 & 0.001 & 0.0 & 0.02 & 21.2 & 40.5 & 21.240 .6 & --- \\
\hline July & 0.0 & 0.001 & 0.0 & 0.0 & 27.4 & 46.4 & 25.344 .1 & --- \\
\hline Total & 175.7 & 342.9 & 464.0 & 446.0 & & & & \\
\hline
\end{tabular}


At maturity a distance of $50 \mathrm{~cm}$ length was chosen at random from middle rows for each plot, and the plants were pulled out and used for yield components study .Data recorded for each plot included plant height $(\mathrm{cm})$, no. of days to heading (when $75 \%$ of the plants in a plot had reached heading), no. of pods per plant, no of seeds per pod,

1000 seed weight $(\mathrm{g})$ and seed yield (taken from the middle two rows and converted to $\mathrm{kg} /$ donum ) . The data were analyzed according to combined variance .For comparison between means,Duncan s'multiple rang test was used (Al-Rawi and Khalafallah,1980) .

Application of safety-first selection indices proposed by Kataoka (1963) and reviewed by Eskridge (1990) were done. This index values (Table 5) were computed from the estimates given in table (2). Variety stability will be based on three different models:

i-The variance of variety across environments (EV) . ii-Finlay and Wilkinson s' regression coefficient (FW) .

iii-both Finlay and Wilkinson s' regression coefficient and Eberhart and

Russell s' deviation mean square (ER) .

Table (2) : safety-first selection indices with three definitions of stability .

\begin{tabular}{|c|c|c|}
\hline Stability definition & Index form for variety I & Abbrev. \\
\hline Variance across environments & y̆i - z(1- $\alpha) S i$ & EV \\
\hline $\begin{array}{l}\text { Finaly and Wilkinson s' regression } \\
\text { coefficient }\end{array}$ & y̆i $-\mathrm{z}(1-\alpha)\left[(\mathrm{bi}-1)^{2} S^{2} \mathrm{y}(1-1 / \mathrm{q})\right]^{1 / 2}$ & FW \\
\hline $\begin{array}{l}\text { Finlay and Wilkinson s' regression } \\
\text { coefficient and Eberhart and Russell } \\
\text { deviation mean square }\end{array}$ & $\begin{array}{c}y \mathrm{i}-\mathrm{z}(1-\alpha)\left[(\mathrm{bi}-1)^{2} S^{2} y(1-1 / q)+\right. \\
\left.S^{2} \mathrm{bi}\right]^{1 / 2}\end{array}$ & ER \\
\hline
\end{tabular}

Where:

y̆i=overall mean of ith variety ;

$\mathrm{z}(1-\alpha)=(1-\alpha)$ percentile from the standard normal distribution ;

$\mathrm{S}^{2} \mathrm{i}$ : variance across environments ;

bi :regression coefficient

$S^{2} y$ : variance of environment means ;

$\mathrm{S}^{2}$ bi: Eberhart and Russell s' deviation mean square from regression .

\section{RESULTS AND DISCUSSION}

The combined analysis of variance showed that genotypes were significantly different in all studied characters except no. of seed per pod and 1000 seeds weight (table 3 ). The highly significant genetic difference among the varieties shows that they must carry genes with different additive effects. The environmental component and the genotype $\mathrm{X}$ environment interaction term were highly significant for all characters except 1000 seed weight suggesting different ranking of varieties in individual environment. Environment (linear) effects was significant for all characters except 1000 seed weight indicating that response to environment is under genetic control (Bradshaw, 1973; Khan and Bradshaw ,1976). Test of pooled deviation vis, pooled error was significant 
at $1 \%$ level for plant height, no. of pods / plant and seed yield which shows that deviation from linearity due to unpredictable in the response to environment are important.

The mean performance and stability parameters for studied characters summarized in table 4. Forte variety gave the tallest plants $(106.1 \mathrm{~cm})$. Meanwhile Paktol came in second rank $(105.8 \mathrm{~cm})$, on the other hand Kebel variety had the shortest plants, this might be attributed to the genetic constitution of each variety. The average data of the environments showed that Paktol variety gave significantly the highest no. of pods per plant and seed yield .Yields overall environments ranged from low of $197.2 \mathrm{~kg} /$ donum for Karat to high of $278.1 \mathrm{~kg} /$ donum for Paktol . Varieties varied in heading dates, Kebel is earlier comparing with other varieties, increased about 10 days greater than Karat, which was late in heading. The studied varieties did not differ significantly in no. seeds per pod and 1000 seed weight .It could be concluded that varietial differences among rapeseed varieties may be due to its genetical differences and this results were accordance with those reported by Fribourg et al.(1990); Christmas (1996); Starner et al. (2002) .

Table (3): Combined analysis of variance.

\begin{tabular}{|c|c|c|c|c|c|c|c|}
\hline \multirow{2}{*}{ SOV } & \multirow{2}{*}{ d.f } & \multicolumn{6}{|c|}{ Mean squares } \\
\hline & & 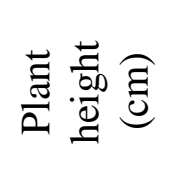 & 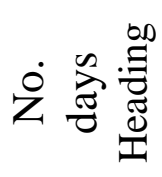 & 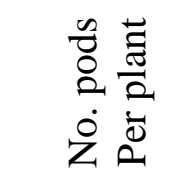 & 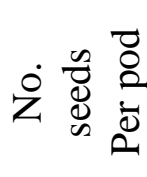 & & 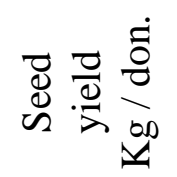 \\
\hline Genotypes & 3 & $564.2 * *$ & $306.1 * *$ & $5643.6^{* *}$ & 4.3 & 0.2 & $21675.2 *$ \\
\hline Environments & 4 & 73.4 & $94.1 * *$ & $99049.3^{* *}$ & $86.6^{* *}$ & $1.8 * *$ & $18146.9 *$ \\
\hline Gen. X Env. & 12 & $547.2 * *$ & $8.7 * *$ & $5695.6^{*}$ & $28.8 * *$ & 0.2 & $13942.2 *$ \\
\hline Env.+Gen.X Env. & 16 & $652.0 * *$ & $10.1 * *$ & $9680.0 * *$ & $14.4 * *$ & 0.2 & 4997.3 \\
\hline Env.(Linear) & 1 & $6112.6^{* *}$ & $94.5^{* *}$ & $98830.5 * *$ & $87.0 * *$ & 0.4 & $18153.9 *$ \\
\hline Gen. X Env(Lin.) & 3 & $1138.8^{* *}$ & $15.9 * *$ & $12261.6 * *$ & $35.0 * *$ & 0.1 & 5777.1 \\
\hline Pooled divation & 12 & $75.3^{* *}$ & 1.6 & $1605.4^{* *}$ & 3.1 & 0.2 & $3706.0 * *$ \\
\hline Pooled Error & 40 & 53.2 & 6.1 & 786.3 & 2.9 & 0.1 & 635.0 \\
\hline
\end{tabular}

*,** significant at $5 \%$ and $1 \%$ level, respectively.

Regression of variety mean on environmental mean and the contribution of individual varieties to $\mathrm{G} X \mathrm{E}$ variance indicated that varieties differed in their genetic potential for responding to a favorable environment. Paktol has (b) values significantly greater than unity for plant height, no. of days to heading and no. of pods per plant which show that this variety was adapted to favorite environment . For seed yield, (b) value not significant higher than unity which indicates that Paktol variety responded well to average environment .This is supported from results reported by Fribourg et al.(1990) ; Williams (1990) and Starner et al. (2002) .Kebel has (b) values significantly

Less than unity for plant height and no. of days to heading which indicates that this variety responded well to unfavorite environments, and significantly 
greater than unity for no. of pods per plant and no. of seed per pods which show adapted to favorite environments .

Safety -first index values shown in table (5). Safety -first selection for stability showed variation in the order of genotype stability for different characters. Paktol exhibited the highest order ( $1^{\text {st }}$ order) for no. pods per plant and seed yield in the three techniques. Kebel exhibited the highest order for no. seeds per pod in EV and FW and 1000 seed weight in FW and ER techniques .Forte variety gave the highest stability rank for plant height . Forte and Karat gaves the lowest order in stability for no. seeds per pod and 1000 seed weight according to the three stability techniques used respectively and the highest order for no. of days to heading in FW and ER techniques. 

Table (4): Mean, variance across environments ( $\left.\mathrm{S}^{2} \mathrm{i}\right)$, Finlay and Wilkinson s' regression coefficient(bi) and Eberhart and Russell s' deviation mean square from regression $\left(\mathrm{S}^{2} \mathrm{bi}\right)$ for genotypes, and variance of environment means $\left(\mathrm{S}^{2} \mathrm{y}\right)$.

\begin{tabular}{|c|c|c|c|c|c|c|c|c|c|c|c|c|}
\hline \multirow{2}{*}{$\begin{array}{l}\text { Genot } \\
\text { ypes }\end{array}$} & \multicolumn{4}{|c|}{ Plant height } & \multicolumn{4}{|c|}{ No. of days to heading } & \multicolumn{4}{|c|}{ Pods per plant } \\
\hline & Mean & $\mathrm{S}^{2} \mathrm{i}$ & bi & $S^{2} b i$ & Mean & $\mathrm{S}^{2} \mathrm{i}$ & bi & $S^{2}$ bi & Mean & $\mathrm{S}^{2} \mathrm{i}$ & bi & $S^{2} b i$ \\
\hline Paktol & $\begin{array}{c}105.8 \\
\mathrm{a}\end{array}$ & 274.4 & $1.6^{* *}$ & 1174.8 & $\begin{array}{c}107.7 \\
\text { c }\end{array}$ & 6.2 & $1.4^{* * *}$ & 0.07 & $\begin{array}{c}177.50 \\
\mathrm{a}\end{array}$ & 1447.5 & $1.1^{* *}$ & 4069.2 \\
\hline Kebel & $\begin{array}{c}99.4 \\
\text { b }\end{array}$ & 139.9 & $0.6^{* *}$ & 169.8 & $\begin{array}{c}104.1 \\
\mathrm{~d}\end{array}$ & 38.0 & $0.7^{*}$ & 0.25 & $\begin{array}{c}168.1 \\
a b\end{array}$ & 1147.2 & $1.2^{* *}$ & 6848.5 \\
\hline Forte & $\begin{array}{c}106.1 \\
\mathrm{a}\end{array}$ & 107.4 & $1.13^{* * *}$ & 529.3 & $\begin{array}{c}112.0 \\
\mathrm{~b}\end{array}$ & 10.0 & $1.4^{* *}$ & 0.86 & $\begin{array}{c}134.7 \\
\mathrm{c}\end{array}$ & 3013.3 & $1.0^{* *}$ & 3260.7 \\
\hline $\begin{array}{c}\text { Karat } \\
\mathrm{S}^{2} \mathrm{y}\end{array}$ & $\begin{array}{c}99.7 \\
b \\
517.7\end{array}$ & 121.7 & 0.7 & 340.4 & $\begin{array}{c}114.2 \\
\mathrm{a} \\
7.9\end{array}$ & 27.4 & $0.6^{* *}$ & 2.33 & $\begin{array}{c}147.7 \\
\text { bc } \\
8258.4\end{array}$ & 1494.9 & $0.7^{* *}$ & 1007.7 \\
\hline \multirow{2}{*}{$\begin{array}{l}\text { Genot } \\
\text { ypes }\end{array}$} & \multicolumn{4}{|c|}{ Seeds per pods } & \multicolumn{4}{|c|}{1000 seeds wt. } & \multicolumn{4}{|c|}{ Seed yield } \\
\hline & Mean & $\mathrm{S}^{2} \mathrm{i}$ & bi & $\mathrm{S}^{2} \mathrm{bi}$ & Mean & $\mathrm{S}^{2} \mathrm{i}$ & bi & $\mathrm{S}^{2} \mathrm{bi}$ & Mean & $\mathrm{S}^{2} \mathrm{i}$ & bi & $\mathrm{S}^{2} \mathrm{bi}$ \\
\hline Paktol & $\begin{array}{c}24.0 \\
\mathrm{a}\end{array}$ & 10 & 0.2 & 5.5 & $\begin{array}{c}3.50 \\
\mathrm{a}\end{array}$ & 0.04 & 0.1 & 0.15 & $\begin{array}{c}278.1 \\
\mathrm{a}\end{array}$ & 8055.4 & 1.6 & 5010.7 \\
\hline Kebel & $\begin{array}{c}22.9 \\
\mathrm{a}\end{array}$ & 4.5 & $1.5^{* *}$ & 4.2 & $\begin{array}{c}3.3 \\
\mathrm{a}\end{array}$ & 0.08 & 0.9 & 0.19 & $\begin{array}{c}198.6 \\
\text { b }\end{array}$ & 2063.0 & 1.2 & 2585.0 \\
\hline Forte & $\begin{array}{c}23.4 \\
\mathrm{a}\end{array}$ & 9.4 & $2^{* *}$ & 3.5 & $\begin{array}{c}3.2 \\
\mathrm{a}\end{array}$ & 0.05 & 1.7 & 0.18 & $\begin{array}{c}216.6 \\
b\end{array}$ & 6052.2 & 0.2 & 4198.9 \\
\hline $\begin{array}{c}\text { Karat } \\
S^{2} y\end{array}$ & $\begin{array}{c}22.8 \\
\mathrm{a} \\
7.3\end{array}$ & 5.7 & 0.3 & 1.6 & $\begin{array}{c}3.2 \\
\mathrm{a} \\
0.4\end{array}$ & 0.05 & 1.7 & 0.51 & $\begin{array}{c}197.2 \\
\text { b } \\
1512.8\end{array}$ & 2383.3 & 1.4 & 1854.8 \\
\hline
\end{tabular}

*** significant at $5 \%$ and $1 \%$ level, respectively. 

Table (5): Values of safety-first selection indices and associated rankings(in parentheses).

\begin{tabular}{|c|c|c|c|c|c|c|c|c|c|}
\hline Genotypes & \multicolumn{3}{|c|}{ Plant height } & \multicolumn{3}{c|}{ No. of days heading } & \multicolumn{4}{c|}{ Pods per plant } \\
\cline { 2 - 11 } & EV & FW & ER & EV & FW & ER & EV & FW & ER \\
\hline Paktol & 84.0 & 85.7 & 46.0 & 103.6 & 106.1 & 106.0 & 114.9 & 164.0 & 123.3 \\
& $(2)$ & $(4)$ & $(4)$ & $(3)$ & $(3)$ & $(3)$ & $(1)$ & $(1)$ & $(1)$ \\
Kebel & 80.0 & 86.0 & 74.1 & 94.0 & 102.9 & 102.7 & 112.4 & 141.4 & 43.7 \\
& $(4)$ & $(3)$ & $(1)$ & $(4)$ & $(4)$ & $(4)$ & $(2)$ & $(2)$ & $(4)$ \\
Forte & 89.1 & 101.5 & 68.0 & 106.7 & 110.4 & 109.8 & 44.4 & 129.4 & 83.7 \\
& $(1)$ & $(1)$ & $(2)$ & $(1)$ & $(2)$ & $(2)$ & $(4)$ & $(3)$ & $(2)$ \\
Karat & 81.6 & 89.6 & 67.7 & 105.6 & 112.6 & 111.2 & 84.1 & 107.6 & 70.2 \\
& $(3)$ & $(2)$ & $(3)$ & $(2)$ & $(1)$ & $(1)$ & $(3)$ & $(4)$ & $(3)$ \\
Genotypes & \multicolumn{2}{|c|}{ Seeds per pods } & \multicolumn{2}{c|}{1000 seeds wt. } & & & Seed yield & \\
& EV & FW & ER & EV & FW & ER & EV & FW & ER \\
\hline Paktol & 18.8 & 19.7 & 18.8 & 3.2 & 2.7 & 2.5 & 130.5 & 243.8 & 156.7 \\
& $(3)$ & $(2)$ & $(3)$ & $(1)$ & $(2)$ & $(2)$ & $(1)$ & $(1)$ & $(1)$ \\
Kebel & 19.4 & 20.2 & 19.0 & 2.8 & 3.1 & 2.6 & 123.9 & 187.2 & 114.2 \\
& $(1)$ & $(1)$ & $(2)$ & $(2)$ & $(1)$ & $(1)$ & $(2)$ & $(2)$ & $(3)$ \\
Forte & 18.4 & 18.0 & 18.4 & 2.8 & 2.6 & 2.3 & 88.6 & 170.8 & 100.6 \\
& $(4)$ & $(4)$ & $(4)$ & $(3)$ & $(3)$ & $(3)$ & $(4)$ & $(3)$ & $(4)$ \\
Karat & 18.9 & 19.0 & 19.4 & 2.7 & 2.5 & 1.9 & 116.9 & 144.3 & 122.5 \\
& $(2)$ & $(3)$ & $(1)$ & $(4)$ & $(4)$ & $(4)$ & $(3)$ & $(4)$ & $(2)$ \\
\hline
\end{tabular}


أستقرارية اصناف من السلجم (Brassica napus L) تحت الظروف المطرية في شمال العراق

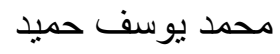

قسم المحاصيل الحقلية ، كلية الزر اعة والغابات ، جامعة الموصل ، العراق

الخلاصة

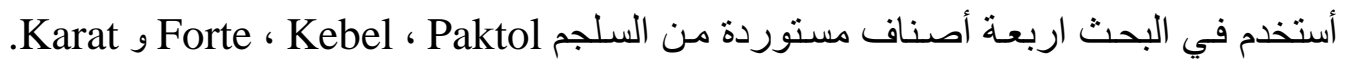

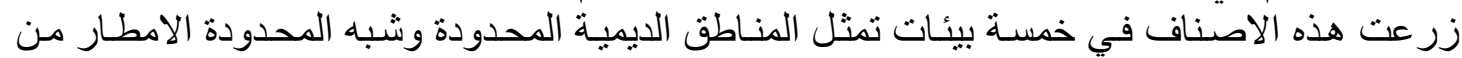

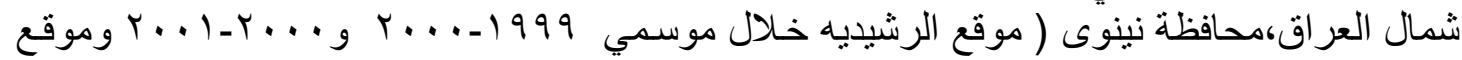

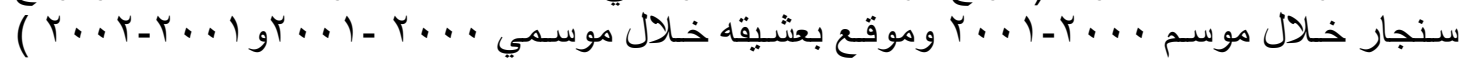

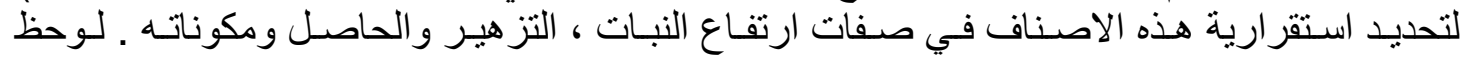

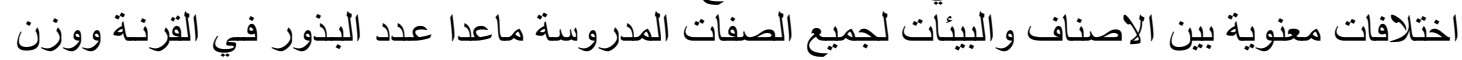

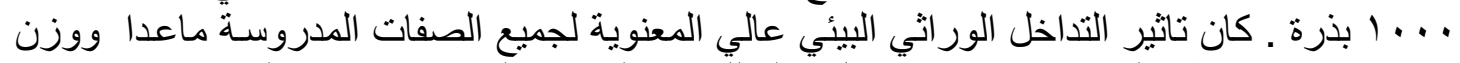

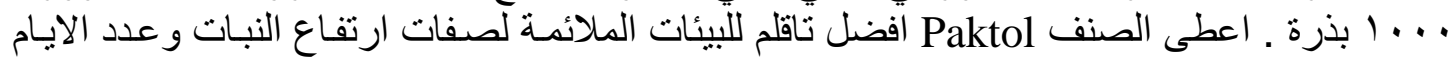

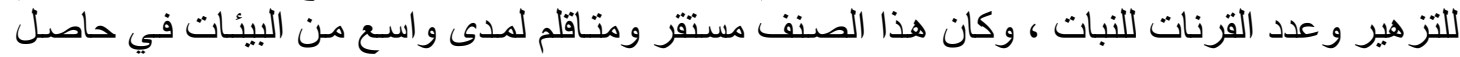

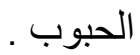

\section{REFERENCES}

Al-Rawi K.M. and A.Khalafallah (1980) .Design and analysis of agricultural expriments. Mosul University Press. Mosul . Iraq.

Bardshaw ,A.D.(1973). Environment and phenotypic plasticity . Brookhaven symposia in Biology , $25: 75-94$

Blum, A. and Y.Pnuel (1990). Physiological attributes associated with drought resistance of wheat cultivars in a Mediterranean environment. Aus. J.Agric. Res., 41:799-810 .

Christmas , E.P. (1996) .Evaluation of planting date for winter canola production in Indiana .P.278-281.In: Janick (ed.), Progress in new crops . ASHS press. Alexandria, VA .

Donald ,C. M. (1968) . The breeding of crop ideotype . Euphytica , 17:385-403

Eskridge ,K.M.(1990) . Selection of cultivars using a saftey-first rule.Crop Sci.,30:369-374.

Fribourg,C.R.,G.N. Graves;Jr.,J.F. Bradley Rhodes and E.C. Bernard Gorezanski (1990). Rapeeseed performance in west Tennessee. P. 228. In: J.Janick and J.E.Simon(eds.), Advances in new crops. Timber press, Portland

Kataoka , S . (1963) . Astochastic programming model .Econometrica ,31:181196.(Crop Sci., 30:369-374 .1990).

Khan , M.A. and A.D. Bradshaw . (1976). Adaptation to heterogeneous environment . II. Phenotypic plasticity in response to spacing in Linum..Aus . J .Agric .Res ., 27 :519-531 .

Kretchme , P.J. ; D.R. Laing and D.H.Wallace (1979) . Inheritance and morphological traits of a phytochrome controlled single gene in bean . Crop Sci ., 19: 605-607 .

Perry. M.W.(1987). Water use efficiency of non-irrigated field crops Proceeding of the $4{ }^{\text {th }}$ Australian Agronomy Conference. La Trope University, Melbourne. PP 83 
Raymer, P.L.(2002).Canola : An emerging oilseed crop .p.122-126. In. J.Janik and A. Whipkey(eds.), Trends in new crops and new uses .ASHS press. Alexandria ,VA.

Starner, D.E.,A.A.Hamama, and H.L.Bhardwaj.(2002).Prospects of canola as an alternative winter crop in Virginia .P.127-130. In: Janick and Whipky (eds.),Trends new crops and new uses. ASHS Press, Alexandria, VA.

Williams, P.H. (1990). Cruciferous oilseeds. P. 228. In: J. Janick and J.E. Simon(eds.) , Advances in new crops. Timber press, Portland, OR. 